This is an open access article under the CC BY-NC-ND license (https://creativecommons.org/licenses/by-nc-nd/3.0/) Issue III, November 2020

ISSN 2707-9481

ISBN 978-601-323-207-2

https://doi.org/10.31643/2020.004

\author{
Aisaule Shyntemirova \\ Abai Kazakh National Pedagogical University, Kazakhstan \\ E-mail: aisaule96@bk.ru \\ ORCID ID: 0000-0003-4819-7167
}

\title{
Features of professional training of future teacher-psychologists
}

\begin{abstract}
The article deals with the problem of training future teacher-psychologists focused on the new content of education, the new educational policy of the Republic of Kazakhstan. Due to the change in the educational paradigm, new tasks and requirements are set for the future specialist. The role of teacher-psychologists in these conditions of development of society is very relevant. It is the teacher-psychologist who helps the student and teacher to master the innovations of the educational system from a scientific and practical point of view. The author traces the effective forms of training specialists.
\end{abstract}

Keywords: teacher-psychologist, competence, motivation, knowledge, formation.

Cite this article as: Shyntemirova A. (2020), Bolaşaq pedagog-psïxologtardıñ käsibï dayarlığınıñ erekşelikteri [Features of professional training of future teacher-psychologists], Challenges of Science. Issue III, 2020. Pp.: 31-34.

https://doi.org/10.31643/2020.004

\author{
Айсауле Шынтемирова \\ Абай ат. ҚазҰПУ магистранты \\ E-mail: aisaule96@bk.ru \\ ORCID ID: 0000-0003-4819-7167
}

\section{Болашақ педагог-психологтардың кәсіби даярлығының ерекшеліктері}

\begin{abstract}
Абстракт: Мақалада білім берудің жаңа мазмұнына, Қазақстан Республикасының жаңа білім беру саясатына бағытталған болашақ педагог-психологтарды даярлау мәселесі қарастырылған. Білім беру парадигмасының өзгеруіне байланысты болашақ маманға жаңа міндеттер қойылады, жаңа талаптар қойылады. Қоғамның дамуы үшін көрсетілген жағдайлардағы білім беру психологтарының рөлі өте өзекті. Оқушыға, оқытушыға ғылыми-практикалық тұрғыдан білім беру жүйесінің жаңашылдықтарын игеруге көмектесетін педагог-психолог. Автор маман даярлаудың тиімді формаларын бақылайды.
\end{abstract}

Түйін сөздер: педагог-психолог, құзырет, мотивация, білім, қалыптастыру.

Кіріспе. Бүгінгі қоғамның дамуы, оның мүшелерінің білімімен өлшенеді. Өйткені, қазіргі өркениетке жеткізетін құрал - білім. Сондықтан білімді ұрпақ тәрбиелеу - бүгінгі қоғамның сұранысы.

Қазақтың кемел талантты ұстазы Ахмет Байтұрсынов: «Елді түзетуді бала оқыту ісін түзетуден бастау керек», -деген $[1,33]$. Мұндай бағыт Елбасымыз Н.Ә. Назарбаевтың «Қазақстандық жол - 2050: Бір мақсат, бір мүдде, бір болашақ» атты Жолдауында еліміз дамуының барлық Стратегиялық бағыттарын жүзеге асыратын қойылып отыр. Республика болашағына бағдар беретін бұл жолдауда «XXI ғасырдағы дамыған ел дегеніміз - белсенді, білімді және денсаулығы мықты азаматтар» - деген [2]. Ал, дамудың негізі білім мен ғылымға келіп тіреледі. Сондықтан да, әлемдегі дамыған елдер сияқты Тәуелсіз елімізде білім жүйесі сапасын жетілдіру ең негізгі өзекті мәселелердің бірі болып отырғаны белгілі. Осыған орай, білім беру жүйесінде жастарға, соның қатарында болашақ мамандарға сапалы білім беріп, олардың үйлесімді дамуы мен тұлға ретінде қалыптасуында ұстаздың кәсіби шеберлік көрсеткіштерінің бірі - жалпы педагогикалық, психологиялық, ғылыми-теориялық, әдістемелік жаңалықтар мен озық тәжірибені жетік меңгерудің маңызы зор. 
Педагог-психологқа тән кәсіби құзыреттілік. Қазіргі педагог-психологтың алдындағы міндеті - ғылым мен техниканың даму деңгейіне сәйкес оқушының білімі терең, іскер және ойлауға қабілетті, әлемдік стандарттар негізінде жұмыс істей алатын құзырлы тұлғаны қалыптастыру. Мұндай талапқа сай қызмет істеу үшін жоғары оқу орнының оқытушылары мен білім алушылары үздіксіз ізденісте кәсіби білікті болуы тиіс.

Әрине, педагог-психологтарды дайындауда инновациялық оқыту нәтижелері өз бетінше әрекет етуі арқылы білімді меңгеруіне ықпал етуі тиіс. Олардың ой-өрісін кеңейтіп, дүниетанымдық көзқарастары мен танымдық белсенлілігін арттыруда, зерттеушілігі арқылы шығармашылық икемділігін дамытуда, біліктілікке ұмтылуда, яғни тұлғаны жан-жақты дамытуды жүзеге асыруда университтердің оқу үдерісіне инновациялық технологияларды енгізу шешуші рөл атқарады және оң нәтиже беретіндігі күмән тудырмайды.

Күнде өзгеріп жатқан валамда уақ̧ыт талабынан құалмай, бәсекеге қ̧абілетті болу үшін бүгінгі педагогикалық-психологиялық білім беру жүйесіне өзгерістер керек. Бұл саладагы өзгерістердің бірі білім мазмұнының жаңңаруына байланысты. Фундаментальды білімнен функционалды білімге ауысу кезеңінде әрине, көзқарастар қайшылығы орын алатыны айқын. Дегенмен, бүгінгі күннің талабы осы. Негізінен жаңартылған білім жүйесі құзыреттілікке және сапаға бағытталған бағдарлама [3]. Жаңартылған білім берудің маңыздылығы - оқушы тұлғасының үйлесімді қолайлы білім беру ортасын құра отырып сын тұрғысынан ойлау, зерттеу жұмыстарын жүргізу, тәжірибе жасау, АКТ-ны қолдану, коммуникативті қарым-қатынасқа түсу, жеке, жұппен, топта жұмыс жасай білу. Сонымен қатар, білім мазмұнының жаңаруы өзге ұлт өкілдеріне қазақ тілі мен әдебиетін оқытудың жаңа механизмдерін, озық тәсілдерін қалыптастыруға мүмкіндік беріп отыр. Ал ең негізгісі - бавалаудың тиімді жаңа стратегиялары. Бағалау жүйесі түбегейлі өзгеріске ұшырап, критериялық бағалау жүйесіне өтті. Қазіргі критериалды бағалауда оқушылардың үлгерімі алдын-ала белгіленген критерийлердің нақты жиынтығымен өлшеніп жатыр. Мұндай өзгерістердің оқушы мен ұстаздың жалпы іс-әрекетіне, ой-өрісіне, психикасына әсер ететіндігі анық. Ал осы кезеңде педагог-психологтың іс-әрекеті де ерекше. Бір сөзбен қорытқанда: педагог-психолог білім алушыларва инновацияларды бейімдеуге, қуабылдауга вылыми-практикалық тұрвыда көмектеседі.

Педагог-психологтарды дайындауда айтарлықтай тағы бір мәселе -кәсіби құзыреттілік. Бұл адам кәсібилігінің қажетті құрамдас бөлігі болып табылады. Сондықтан кәсіби құзыреттілік мәселесі отандық және шетел ғалымдарының жұмыстарында кеңінен қарастырылады [4-15]. Кәсіби құзыреттіліктің заманауи бағыттары және түсіндірмелері тіптен әртүрлі. Шетел әдебиеттерінде бар кәсіби құзыреттілік анықтамалары, яғни «терең білім», «тапсырманы адекватты орындау күйі», «қызметті өзекті орындау қабілеттері» және басқалары бұл ұғымның мазмұнын толық нақты түсіндіре алмайды. Сонымен қатар, отандық ғалымдарда кәсіби құзыреттілік мәселесімен белсенді түрде айналысуда. Көп жағдайда бұл ұғым біліктіліктің жоғары деңгейін және кәсібилікті айқындау үшін ішкі оймен пайдаланылады. Кәсіби құзыреттілік маманның дайындық сапасының сипаттамасы, еңбек қызметінің тиімділік әлеуеті ретінде қарастырылады. Педагогикада бұл категория «жалпы мәдени құзыреттіліктен» туындаған өнімді компонент ретінде немесе «маманның білімділік деңгейі» ретінде қарастырылады. Егер кәсіби шеберлік деңгейлер жүйесінде құзыреттілік орнын анықтайтын болсақ, онда ол орындаушылық пен кемелдену арасында орналасқан.

Педагог-психологқ̧а тән кәсіби құзыреттіліктің төрт түрі бар:

1. Арнайы, немесе қызметтік кәсіби құзыреттілік жоғары кәсіби деңгейде қызметті меңгерумен және тек арнайы білімді игеріп қоймай, сонымен бірге оны тәжірибеде қолдануды білумен сипатталады.

2. Жеке кәсіби құзыреттілік өзін-өзі көрсету және өзін-өзі дамыту әдістерін, кәсіби деформацияға қарсы тұру құралдарын меңгерумен сипатталады.

3. Әлеуметтік кәсіби құзыреттілік кәсіби қоғамдастықта қабылданған кәсіби қарым-қатынас тәсілдерін, біріккен кәсіби қызмет және серіктестік әдістерін игерумен сипатталады.

4. Жеке (индивидуальды) кәсіби құзыреттілік өзін-өзі басқара білу тәсілдерін, кәсіби өсуге дайындық, кәсіби қартаюға берілмеу, кәсіби мотивацияның табанды болуы қасиеттерін меңгерумен сипатталады. Құрамына білім мен қабілет қамтитын жеке маманның тұлғасының ерекшеліктері мен ішкі психологиялық құраушылардың қүрделі жүйесі болып табылады.

Инновациялық үрдістердің жалғасуына ықпал етудің маңызды факторының бірі - педагогпсихологтың кәсіби шеберлігі. Солай бола тұра «кәсіби шебер» түсінігіне пәндік, дидактикалық, әдістемелік, психология-педагогикалық білім мен дағды ғана емес, маманның жеке тұлzалық әлеуеті, кәсіби құндылықтары да жатады. 
Педагог-психологтарды дайындауда оның қызметі өте күрделі, әрі көп салалы екендігін ерекше атап айту қажет. Өйткені, ол оқушының жеке басының дамуын, қалыптасуын, оған тәрбие беру, психологиялық тұрғыдан бағыт-бағдар беру процесін басқарады. Осындай маңызды іске жауапты болғандықтан маманнан жан-жақты терең ғылыми білім, жоғары педагогикалықпсихологиялық шеберлік, саяси моральдық қасиет, табанды ерік-жігер, парасатты мінез-кұлық талап етіледі.

Болашақ̆ педагог-психологтің кәсіби маңыззды қ̧асиеттерін қ̧алыптастыруда мынадай негізгі құасиетерге көңіл бөлу қุажет:- оқушыларға деген сүйіспеншілігі; - педагогикалык, процесті жүйелі жүргізе алуы; - бақылағыштығы; - педагогикалық, құбылыстарға талдау жасай алуы; - педагогикалқк, ойлаудың қалыптасуы; - қарым-қатынас жасай алуы; - ұжымшылдық мен шығармашылығы және т.б.

Педагогикалық іс-әрекет қызығы да, қиындығы да мол кызмет. Оның тұлғасын сипаттайтын негізгі кәсіби маңызды қасиеттері маманның педагогикалық әдебінің көрсеткіші де болып табылады. Ал педагог-психологтың кәсіби маңызды қасиеттері ретінде оның балаға деген ынта-ықыласын, сүйіспеншілігн, педагогикалық еңбекке қызығушылығын, психологиялық-педагогикалық сезгіштігін, байқағыштығын, әділдігін, талап қоя білушілігін, табандылығын, ұстамдылығын, өзін-өзі басқара білуін, қайырымдылығын, мейірімділігін, кәсіби еңбекті сүйе білуін, ғылыми ой-өрісінің тереңдігін, рухани танымдық қызығушылығын, интеллектуалдық белсенділігін, өздігінен білім алуға ынталылығын, шығармашылықпен ынтымақтастықты қолдауын, жаңашыл педагогтардың, психолог пен әлеуметтанушының идеяларын түсінуін, қабылдауын атап өтуге болады.

Педагог-пихологты даярлауда оның кәсіби шеберлігінің негізін қ̧алайтын қ̧асиеттерді дамыту қ̧ажет:

Біріншіден, өмірге көзқарасы, идеялық нанымы.

Екіншіден, диагностика, мониторинг, тағы да басқа педагогика және психология салаларының пәнін жетік білуі, ойын оқушыларға жеткізу үшін жан-жақты, терең дайындалуы.

Үшіншіден, оқыту мен тәрбиелеудің әдіс-тәсілдерін табысты қолдана білуі.

Сонымен, педагог-психолог шығармашылық әлеуетін дамыта отырып, өзінің құзіреттілік аясын кеңітеді.

Қорытынды. Қорыта айтқанда, жаңа бағдарламаның мектепке енуі, баланың функционалдық сауаттылығын қалыптастыру - педагог-психолог қызметінің нысаны болып табылады. Жоғары оқу орнында болашақ маманның бойына XXI ғасырда өмірдің барлық салаларында табысты болу үшін, қажетті дағдыларды дарыту керек. Жаңартылған оқу бағдарламасы аясында тек өз қызметін, өз мамандығын шексіз сүйетін, бала үшін ұстаз ғұмырын құдіретті деп санайтын білімді тұлға ғана жұмыс істей алады. Үнді халқының тарихи тұлғасы Махатма Гандидің «Егер сен болашақтағы өзгерісті байқағың келсе, сол өзгерісті уақытында жаса» - деген ілімін негізге ала отырып, болашақ маманның бойындағы қабілетті жетілдіріп, жақсы әдіс-тәсілдер арқылы білім беру - қажетті міндет болып табылады. Ал мектеп қабырғасына барған жас маман жан-жақты білімімен, шеберлігімен, оқытудың жаңа әдістерін меңгеруімен өлшенеді. Педагог қаншалықты білімді, шығармашыл болса, оның құзыреттілік аясы да соғұрлым кең болмақ.

Алғыс: Бұл зерттеуді Абай атындағы Қазақ Ұлттық педагогикалық университетінің педагогика және психология кафедрасының меңгерушісі профессор Айгерім Көшербаеваның қолдаумен орындалды. Автор профессор А. Көшербаеваға ғылыми бағыт бергені үшін алғыс білдіреді.

Мақалаға сілтеме: Шынтемирова А. (2020), Болашақ педагог-психологтардың кәсіби даярлығының ерекшеліктері. Challenges of Science. Issue III, 2020. Pр.: 31-34. https://doi.org/10.31643/2020.004

\section{Қолданылған әдебиет тізімі}

[1]. Байтұрсынұлы А. Әліпби астарың-Алматы,1996

[2]. «Қазақстандық жол - 2050: Бір мақсат, бір мүдде, бір болашақ»- Қазақстан Республикасы Бірінші Президентінің Қазақстан Халқына Жолдауынан. 17 қаңтар 2014 жыл // Егемен Қазақстан. 18 қаңтар. Источник: https://ehistory.kz/kz/contents/view/2129

[3]. ҚР орта білім мазмұнын жаңарту еңберінде қазақ тілінде оқытатын мектептердегі педагогика кадрларының біліктілігін арттыру курсының білім беру бағдарламасы -Астана, 2016.

[4]. Маркова А.К. Кәсіби құзыреттіліктің даму деңгейі - М., 2009 
[5]. Кошербаева А.Н. Парадигма оценки качества высшего образования в Казахстане: реалии и тенденции. «Образование и мегаполис: партнерство для устойчивого успеха.- Сборник ст.по итог.Первого ежегодн. Межд. симпозиума «Образование и Мегаполис: партнерство для устойчивого успеха» - М. . МГПУ, Экон-информ, 2018.

[6]. Тұрғанбекова Б. «Мұғалімнің шығармашылық әлеуетін біліктілікті арттыру жағдайында дамыту: теория және тәжірибе» - Алматы, 2005

[7]. Құдайбергенова К. «Құзырлылық - тұлға дамуының сапалық критерийі» (ғылыми-практикалық конференция материалдары) - Алматы, 2010

[8]. Arpentieva, M. R., Kassymova, G., Kenzhaliyev, O., Retnawati, H., Kosherbayeva, A. (2019). Intersubjective Management in Educational Economy. Challenges of Science. https://doi.org/10.31643/2019.004

[9]. Atayeva, M., Putro, N. H. P. S., Kassymova, G., Kosbay, S. (2019). Impact of reading on students' writing ability. Challenges of Science. https://doi.org/10.31643/2019.001

[10]. Kassymova, G. (2018). Competence and its implications. Challenges of Science. https://doi.org/10.31643/2018.063

[11]. Triyono, B.M., Mohib, N., Kassymova, G.K., Pratama, G.N.I.P., Adinda D., Arpentieva, M.R. (2020). The Profile Improvement of Vocational School Teachers' Competencies. Vysshee obrazovanie v Rossii = Higher Education in Russia. Vol. 29, no. 2, pp. 151-158. https://doi.org/10.31992/0869-3617-2020-29-2-151-158

[12]. Fauzi, C., Basikin, Duisenbayeva, S., Kassymova, G. (2020). Exploring EFL Students Teacher Readiness and Gender Differences of Learner Autonomy. Bulletin the National Academy of Sciences of the Republic of Kazakhstan, 1(383), 288299. https://doi.org/https://doi.org/10.32014/2020.2518-1467.34

[13]. Kenzhaliev B.K., Kul'deev E.I., Luganov V.A., Bondarenko I.V., Motovilov I.Y., Temirova S.S. (2019). Production of Very Fine, Spherical, Particles of Ferriferous Pigments from the Diatomaceous Raw Material of Kazakhstan. Glass and Ceramics, 76(5-6), 194-198. https://doi.org/10.1007/s10717-019-00163-w

[14]. Lavrinenko S. V., Gorelova I. V., Kassymova K. G., Kubantseva O. V., Khudyakova T. L., Yusipova I. V., Arpentieva M. R. (2020). Problems of context and conceptual management in education: psychological, social and economical aspects. Bulletin the National Academy of Sciences of the Republic of Kazakhstan, 1(383), 264-276. https://doi.org/10.32014/2020.2518-1467.32

[15]. Atayeva, M., Ciptaningrum, D. S., Hidayah, R., Kassymova, G. K., Dossayeva, S. K., Akmal, A. (2019). Cultivating Junior High School Students' Critical Thingking Skills by Using a Short Video in English Language Classroom. Bulletin the National Academy of Sciences of the Republic of Kazakhstan, 5(381), 57 - 69. https://doi.org/https://doi.org/10.32014/2019.2518-1467.124

\section{Refrences}

[1]. Baitursynov A. The Alphabet of Yours - Almaty, 1996

[2]. "Kazakhstan's way - 2050: A common goal, common interests, common future" - from the Message of the First President of the Republic of Kazakhstan to the People of Kazakhstan. January 17, 2014 // Sovereign Kazakhstan. January 18. Source: https://e-history.kz/en/contents/view/2129

[3]. Educational program of refresher courses for pedagogical staff in schools with Kazakh language of instruction in updating the content of secondary education in the Republic of Kazakhstan - Astana, 2016.

[4]. Markova A.K. Level of professional competence development - M., 2009

[5]. Kosherbayeva A. N. The paradigm of the highest quality of education in Kazakhstan: realities and trends. "Education and the metropolis: Partnership for sustainable water supply. - Sornorn st. Interd. Symposium "The Education and the Metropolis: Part of the Future" - M. . MSPU, Economics, 2018.

[6]. Turganbekova B. "Development of teacher creative potential in the context of professional development: theory and practice" - Almaty, 2005

[7]. Kudaibergenova K. "Competence - a qualitative criterion of personality development" (Proceedings of the Scientific and Practical Conference) - Almaty, 2010

[8]. Arpentieva, M. R., Kassymova, G., Kenzhaliyev, O., Retnawati, H., Kosherbayeva, A. (2019). Intersubjective Management in Educational Economy. Challenges of Science. https://doi.org/10.31643/2019.004

[9]. Atayeva, M., Putro, N. H. P. S., Kassymova, G., Kosbay, S. (2019). Impact of reading on students' writing ability. Challenges of Science. https://doi.org/10.31643/2019.001

[10]. Kassymova, G. (2018). Competence and its implications. Challenges of Science. https://doi.org/10.31643/2018.063

[11]. Triyono, B.M., Mohib, N., Kassymova, G.K., Pratama, G.N.I.P., Adinda D., Arpentieva, M.R. (2020). The Profile Improvement of Vocational School Teachers' Competencies. Vysshee obrazovanie v Rossii $=$ Higher Education in Russia. Vol. 29, no. 2, pp. 151-158. https://doi.org/10.31992/0869-3617-2020-29-2-151-158

[12]. Fauzi, C., Basikin, Duisenbayeva, S., Kassymova, G. (2020). Exploring EFL Students Teacher Readiness and Gender Differences of Learner Autonomy. Bulletin the National Academy of Sciences of the Republic of Kazakhstan, 1(383), 288-299. https://doi.org/https://doi.org/10.32014/2020.2518-1467.34

[13].Kenzhaliev B.K., Kul'deev E.I., Luganov V.A., Bondarenko I.V., Motovilov I.Y., Temirova S.S. (2019). Production of Very Fine, Spherical, Particles of Ferriferous Pigments from the Diatomaceous Raw Material of Kazakhstan. Glass and Ceramics, 76(5-6), 194-198. https://doi.org/10.1007/s10717-019-00163-w

[14]. Lavrinenko S. V., Gorelova I. V., Kassymova K. G., Kubantseva O. V., Khudyakova T. L., Yusipova I. V., Arpentieva M. R. (2020). Problems of context and conceptual management in education: psychological, social and economical aspects. Bulletin the National Academy of Sciences of the Republic of Kazakhstan, 1(383), $264-276$. https://doi.org/10.32014/2020.2518-1467.32

[15]. Atayeva, M., Ciptaningrum, D. S., Hidayah, R., Kassymova, G. K., Dossayeva, S. K., Akmal, A. (2019). Cultivating Junior High School Students' Critical Thingking Skills by Using a Short Video in English Language Classroom. Bulletin the National Academy of Sciences of the Republic of Kazakhstan, 5(381), $57 \quad-\quad 69$. https://doi.org/https://doi.org/10.32014/2019.2518-1467.124 